http://dx.doi.org/10.1590/0370-44672020740127

\section{Cecília Ribeiro Tourino Costa ${ }^{1,4}$ \\ https://orcid.org/0000-0002-2249-7834 \\ Marcela Laert Moreira ${ }^{2,5}$ \\ https://orcid.org/0000-0001-6571-6323 \\ Aloysio Portugal Maia Saliba ${ }^{3,6}$ \\ https://orcid.org/0000-0002-0149-3295 \\ 1TEC3 Geotecnia e Recursos Hídricos Ltda., \\ Belo Horizonte - Minas Gerais - Brasil. \\ ${ }^{2}$ Universidade Federal de Minas Gerais - UFMG, Programa de Mestrado em Geotecnia e Transportes, Departamento de Engenharia de Transportes e Geotecnia, Belo Horizonte - Minas Gerais - Brasil \\ ${ }^{3}$ Universidade Federal de Minas Gerais - UFMG, Departamento de Engenharia Hidráulica e Recursos Hídricos, Belo Horizonte - Minas Gerais - Brasil. \\ E-mails: ${ }^{4}$ cecirtcosta@gmail.com, \\ ${ }^{5}$ marcela.laert09@gmail.com, ${ }^{6}$ asaliba@ehr.ufmg.br}

\section{Introduction}

The introduction of solar parks in Brazil is a recent and prominent enterprise, especially considering environmental requirements related to clean and renewable energy. Solar parks are distinguished environments in terms of water drainage and erosion control. During implementation and in the operation phase of solar parks, some topics are of great relevance for understanding erosion. There is the removal of vegetation cover and topsoil, the formation of sites that concentrate the water flow, and changes in the park surface. Therefore, solutions for erosion control must be investigated, mainly to cover all aspects of the enterprise, promoting less risk and more effective measures.

Issues related to erosion are still

\section{Chemical stabilization with lime}

The definition by NBR 6453 (2003) addresses lime as a "product obtained by the calcination of calcium carbonates, magnesium carbonates, or both. consisting essentially of a mixture of magnesium

\title{
Civil Engineering Soil stabilization with lime for erosion control in solar plants
}

\begin{abstract}
The installation of solar parks requires extensive areas and results in soil erosion in many cases. One suitable solution is applying lime to improve soil characteristics, such as mechanical strength, stability, workability, durability, and internal and surface erosion resistance. This soil treatment is of particular importance when dealing with hydraulic structures conceived in the solar park drainage systems. The erodibility tests were performed in a solar complex soil in an EFA apparatus constructed to measure the erosion rate of cohesive and non-cohesive soils in different flow rates. The tests were performed with or without $3 \%$ lime addition and two compaction conditions. The experiments indicated that the erodibility of lime-treated soils represents between $26 \%$ and $12 \%$ of the values obtained from untreated soils and under reduced compaction. The values ranged from $16 \%$ to $7 \%$ for controlled compaction. The results represent a significant reduction in the soil erodibility treated with lime even with reduced compaction, performing an efficient, economical, and sustainable solution for erosion control.
\end{abstract}

Keywords: erosion, soil stabilization, lime, solar plant.

considered complex, with a multivariate influence of factors, causing several socio-environmental and economic consequences. Erosion consists of a set of disaggregation processes of the earth's crust materials by erosive agent actions (Vilar, 1987). One aspect of great relevance to understanding erosion processes is erodibility. Erodibility links to the soil's inherent properties, such as texture, apparent density, porosity, structure, soil particle size percentages, organic matter content, and soil permeability (Bertoni \& Lombardi Neto, 1999).

Among the soil stabilization methods, chemical stabilization is mentioned, which consists of modifying soil properties through reactions between soil grains and products added. One of these methodologies is the addition of lime to soils, which triggers chemical reactions between the mineralogical constituents of the soil, such as clay and lime. The lime potential to improve the compacted soil's mechanical characteristics for geotechnical works is recognized as a soil treatment technique. Several authors showed that lime treatment primarily improves soil workability and strength (Mehenni et al., 2016). As a result, the lime-treated grounds are of great interest for solar parks, as it is a resource capable of meeting three fundamental needs: efficiency, economy, and sustainability (Neves, 2009). Thus, soil condition improvement is an attractive option, ensuring better stability, durability, and water erosion resistance (Sales et al., 2017). oxide, or a mixture of calcium oxide, magnesium oxide, and calcium hydroxide." According to this standard, there are different lime types for construction, the most notable being aerial lime and hydraulic lime, with the latter being the most used in soil stabilization.

Today, soil stabilization with lime is a well-known technique in earthworks, including highways, embankments, dikes, 
airports, foundation bases, among others (Wilkinson et al., 2010). Chemical stabilization with lime addition has as its main results increased mechanical resistance and greater soil workability and durability: lime reactions with the particles of clay minerals developed in an environment with high $\mathrm{pH}$ cause these changes.

Soil stabilization with lime is a technique commonly used in earthworks since the middle of the past century. In literature, this treatment technique is related only to fine-grained soils like silty soils or clayey soils (Elandaloussi et al., 2018). They have a complex structure of less than $2 \mu \mathrm{m}$ marked by low permeability, large specific surface, plastic behavior in the presence of water, and water adsorption capacity due to its negative electrical charge indicated in NBR 6502 (1995).

Mixing lime in wet soil allows water to impose the formation of calcium ions $\left(\mathrm{Ca}^{++}\right)$, providing a high concentration of free cations willing to permanently replace other metal ions in the soil, which characterizes a phenomenon called cationic exchange (Dalla Rosa, 2009). Such a reaction relates to the soil's mineralogical characteristics and cations, which may provide a stable combination, where fewer cations could modify the new configuration.

After ion exchange, the ionic attraction between particles increases, resulting in a cluster that changes the laminar flow and increases isotropic behavior. Another factor that favors particle clustering is the reduction of the double layer in the ions. The physical effect of the flocculation between clay and lime particles can be considered similar to an increase in particle diameter, subsequently increasing the frictional resistance between them (Azevedo et al., 1998). Also, there is a rearrangement in the grain size curve approaching the coarser side, affecting the plasticity index, whereby maximum dry density reduces, and optimum moisture content as well (Neves, 2009). However, the soil's strength gain will typically more than compensate for the compaction optima changes, and they should not be regarded as disadvantageous (Bell, 1996).

Another relevant process is soil cementation caused by the chemical reaction between lime, water, and the soil's pozzolanic elements. The reactions create the calcium silicate and aluminum hydrates, similar to the product obtained by hydrating Portland cement in concrete and soil-cement (Azevedo et al., 1998). These reactions are irreversible. The increase in shear strength and cohesion in the long term is related to the cementation reactions mentioned above. Studies show that cohesion is increasingly improved for up to two years of application while the friction angle is stable with lime (Herrier et al., 2013).

The fourth process identified is carbonation, a reaction between lime and carbon dioxide in the air. Azevedo (2010) states that carbonation should be avoided, as it decreases the availability of calcium cations in the clay's particle surface, impairing the pozzolanic reactions that create cementing compounds with increased resistance. Therefore, it is necessary to protect the stabilized layer from the carbon dioxide in the air.

The reaction efficiency from treating the soil with lime is affected by several factors, such as its percentage of clay, plasticity index, mineralogical characteristics of the clay, and certain undesirable substances for reactions (sodium, potassium, sulfate, and organic matter). Besides this, for such pozzolanic reactions to occur, the $\mathrm{pH}$ of the medium must be high $(\mathrm{pH}>10.5)$ so that silica and aluminum release from the clay particles (Neves, 2009).

The dosing methods indicated by Neves (2009) are available in French standards and manuals that establish dosing methods for treating soils used in capping layers and embankments. The most used procedure's primary objective is to identify the lime dosing, which produces the greatest resistance, highlighting the Texas method, the Eades and Grim $\mathrm{pH}$ test, and the Geotechnical Testing Services (GTS) method:

- Texas method - The percentage of lime is selected based on the particle size and Plasticity Index (PI);

- Eades and Grim pH test-To determine the lowest percentage added to the soil to achieve a $\mathrm{pH}$ increase of up to 12.4. This procedure is widely used in Brazil for application on roads (Lovato, 2004);

- GTS method - The used parameter is the soil bearing capacity and its moisture at the application moment. This method indicates that all laboratory tests must be conducted to characterize the soil, lime, and the soil-lime mixture.

Usually, the amount of lime used to improve soils is between $3 \%$ and
$9 \%$, and the curing time used ranges from 7 to 360 days (Jair et al., 2018). The curing time effect in the internal erosion rate measured by Hole Erosion Test (HET), as reported by Herrier et al. (2018), showed an expressive reduction for the erosion coefficient for longer curing times (measured after 3, 7 and, 14 days). The application of lime treatment for capping layers and embankments is already widespread. However, this field is still under evaluation regarding its use for hydraulic structures. Recent studies have investigated the application in levees, canals, small dams, and detention basins. Functions such as workability, stability, and low permeability have been extensively studied and have consolidated references. However, internal and surface erosion and runoff issues must be further investigated to expand this technique's use in hydraulic works.

According to Herrier et al. (2018), several studies carried out by the DigueEllite project in 2013 allowed the evaluation of levees built with compacted soil with added lime and natural hydraulic lime. The main conclusions obtained through the various experiments demonstrated the following benefits:

- Stability: increased mechanical strength enabled the use of slopes with greater inclinations. Such an increase is advantageous in cases of low material availability and limited space;

- Low permeability: the results showed that the lime-treated soils could maintain the same level of permeability as untreated soils without requiring additional impermeability systems;

- Internal resistance to erosion: allows simplification of filters and the drainage system. However, it is still mandatory to study internal erosion protection in the dam/foundation interface. Limited filters and drain devices can simplify the section for construction and reduce the need for materials that may not always be available on site;

- Surface protection: the embankment treated with lime is resistant to erosion and did not require other surface protections, such as rip-rap and gabions;

- Runoff resistance: resistance at high flow velocities may be the main benefit of treating soils with lime. If the dam is resistant to flow velocity, it may play the role of an emergency spillway. However, specific studies must be carried out to prove the compatibility required by the project. 


\section{Case study}

The case study refers to a Solar Power Station with a power generation potential of $132 \mathrm{MW}$ and approximately 320 ha. The station plan consists of 487,080 panels, 36 solar inverters, an access network of roughly $16 \mathrm{~km}$, and a fence of approximately $11 \mathrm{~km}$.

The park's construction took one and a half years. According to Sales et al. (2017), the problem usually begins in the site's implementation phase, with deforestation, the opening of roads without proper occupation planning, and lack of infrastructure, such as drainage systems. There was continuous removal of vegetation cover from the topsoil in the study area. In this stage, the first rainfall events resulted in erosion and sediment transport to locations outside the park.

As already explained, vegetation is a significant factor in erosion control and topsoil removal. Besides implying the loss of organic matter, it increases soil erodibility and results in the loss of the substrate necessary for plant growth. In sites where the topsoil is not replaced or contaminated with the subsoil, the delay in establishing the total vegetation can last some years, leaving it unprotected and with greater susceptibility to erosion.

Another notable factor is related to possible changes in the park topography. Usually, it is necessary to flatten the surface to standardize the solar panel arrangement, which may change the runoff regime due to removing small depressions that served as water storage and remodeling the preferred

\section{Materials and methods}

The methodology adopted to prove the increased resistance to erosion of lime-treated soils consisted of testing in an apparatus developed at CPH/UFMG. Soil sampling occurred in the area of the implementation of a Solar Plant.

The Erosion Function Apparatus (EFA) is a closed box apparatus developed and presented by Briaud et al. (2001), capable of measuring the ero- waterways. All exposed soil surfaces, such as disposal sites, are subject to erosion, requiring sediment containment structures.

Evaluations in points that concentrate flow are also of great interest for studying the problem. According to Sales et al. (2017), linear works are more susceptible to erosive processes since they concentrate and accumulate flow. In solar parks, there are accesses, transmission lines, canals, and fences with grade beams. In general, the requirements for defining the road and fence network may not take into account the topography, resulting in less desirable areas in the site, such as natural thalwegs.

However, sediment and dust from machinery traffic negatively affect the drainage system from silting, energy generation efficiency of solar panels from dust deposition, and internal accesses of the park during drought periods to dust control. All these points generate costs for the enterprise, which could be minimized using the aforementioned soil treatments, such as lime addition.

Usually, the choice for erosion control is installing a drainage system that uses access arrangements to install drainage ditches and canals that can receive and convey rainwater to a detention basin or energy dissipators. Auxiliary structures, such as windrows, terracing, and gabion walls have also been proposed to reduce the flow velocity and retain sediments. It is worth mentioning that other solutions have been sought in other facilities. The use of gravel to cover the entire length of a Solar Park is an example.

Proper planning for works of this size is vital to control the risk of erosion and removal of vegetation. Avoiding the topsoil removal to the maximum and prioritizing the implementation of drainage is essential for its prevention.

The application of lime in the soil in specific areas can provide an attractive solution from environmental, economic, and efficiency perspectives. Also, it addresses issues of erosion control and dust dispersion over the panels and stable hydraulic structures in the drainage system.

One essential aspect is identifying structures that concentrate flows, thalwegs with high slopes, and energy dissipators in a first assessment. It is then possible to adopt channels dug in stabilized soils, depending on the slope conditions and the flow projected. The benefits of these measures ensure better stability and durability, requiring fewer maintenance efforts and providing less risk of erosion for the enterprise.

It is noteworthy that the application should be evaluated for other environments that also present issues related to erosion, such as mining facilities, for example. Modern mining technology can significantly impact the surrounding landscape by eliminating vegetation and permanently altering topography, soils, and subsurface geological structures. (Zhang et al., 2015). sion rate of cohesive and non-cohesive soils subjected to different flow velocities. The results indicate a relationship of erosion to flow velocity and shear stress. Erodibility is a function of the time interval needed to erode a sample with a predetermined height completely.

The EFA apparatus was developed at the Hydraulic Research Center (CPH/UFMG) to determine soil erod- ibility. The test apparatus was made of steel, with an acrylic inspection box. It consists of a motor pump set with a maximum capacity of up to $68 \mathrm{~m}^{3} / \mathrm{h}$, which establishes a mean maximum flow velocity of $2.5 \mathrm{~m} / \mathrm{s}$ inside the test box (Figure 1 - Mantovanelli, 2016). A $45 \mathrm{~mm}$ diameter PVC pipe guides the soil sample rise in the bottom center of this box.

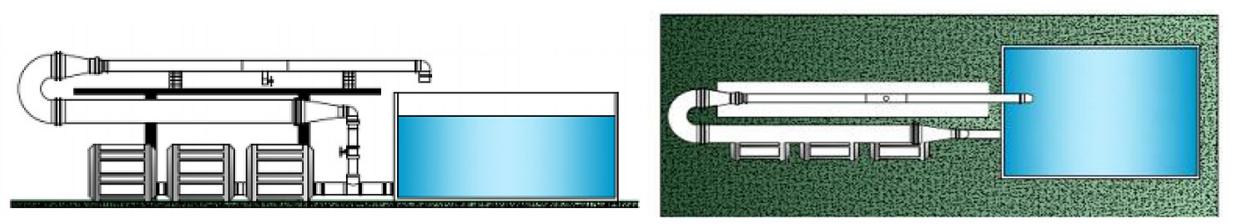

Figure 1 - Side and plan view of the test apparatus - EFA (Source: Mantovanelli, 2016). 
Soil samples were collected on a Solar Complex, described as sandy clay, red, according to geotechnical classification taken from SPT survey reports (Standard Penetration Test). They showed a mean optimum moisture content of $27.2 \%$ and maximum specific dry weight of $1.48 \mathrm{~g} / \mathrm{cm}^{3}$ from geotechnical testing, used to mold the soil samples tested in the EFA.

According to Neves (2009), most soils require between $2 \%$ and $5 \%$ of lime by mass in their treatment. In these testings, it was considered an intermediate value of $3 \%$. Also, the authors considered that the optimum moisture content increases from $0.5 \%$ to $1.0 \%$ with the addition of lime for the same compaction energy to be used on lime hydration reactions with the soil (Azevedo et al., 1998).

Tests on the natural soil's erosive behavior and the lime-treated soil included different flow velocities using an apparatus similar to the EFA presented by Briaud et al. (2001). The tests were carried out on twenty-three samples built using natural and $3 \%$ lime added soil, both subjected to flow velocities of $1.00 \mathrm{~m} / \mathrm{s}, 1.75 \mathrm{~m} / \mathrm{s}$, and $2.50 \mathrm{~m} / \mathrm{s}$. The soil samples were prepared using Proctor Normal and 30\% Proctor
Normal compaction energies to simulate ideal and equipment traffic soil compaction during the installation period. The cylindric samples had a $40 \mathrm{~mm}$ diameter and $16.5 \mathrm{~cm}$ of height.

The methodology used to prepare the samples consisted of six steps: (I) Determination of the natural soil moisture using microwaves, according to criteria provided by Tavares et al. (2008); (II) Addition of water to ensure the optimum compaction moisture $\left(\mathrm{w}_{\mathrm{ot}}=27.2 \%\right)$; (III) Addition of 3\% in a part of the sample, homogenizing the soil with the content of water corresponding to the optimum moisture, having the dry weight of the soil added with lime as a reference; (IV) Compaction of samples in three layers of $5.5-\mathrm{cm}$ using a $1.075 \mathrm{~kg}$ hammer with a drop height of $5 \mathrm{~cm}$ and 76 hammer blows, considering the same compaction energy in the Normal Proctor (NP) test; (V) Compaction with $30 \%$ of the NP energy (26 hammer blows); (VI) Storage of samples for one week as curing time for soils with lime addition previous to EFA testing, suggested as the minimum curing time needed by Baldovino et al. (2018).

EFA tests followed the steps below:

$$
\dot{\mathrm{Z}}=\frac{\partial z}{\partial t}=\frac{h}{t}
$$

eroded soil sample $(\mathrm{mm})$, and $t$ is the time required for the total erosion of
1. Raising the sample manually with the aid of a reference tube having a $1.0 \mathrm{~mm}$ height measured with a tape (Figure 2);

2. Adjusting flow to obtain the desired mean flow velocity, using frequency inverters; the mean velocities obtained were $1.00 \mathrm{~m} / \mathrm{s}, 1.75 \mathrm{~m} / \mathrm{s}$, and $2.50 \mathrm{~m} / \mathrm{s}$;

3 . Recording the time required for complete erosion of the sample through visual inspection. If the testing time exceeded $5 \mathrm{~min}$, testing stopped, and erodibility determined from the measured height eroded.

The flow speed used took into account the motor pump's flow capacity $\left(68 \mathrm{~m}^{3} / \mathrm{h}\right)$, resulting in a flow speed of $2.50 \mathrm{~m} / \mathrm{s}$ for the box dimensions. The lowest flow speed was equal to the erosion onset velocity limit for cohesive compacted soils, according to Chow (1959), which is approximately $1.00 \mathrm{~m} / \mathrm{s}$. Therefore, tests included an intermediate measurement at the middle of this velocity interval $(1.75 \mathrm{~m} / \mathrm{s})$.

Recording the time necessary to erode the height of the soil sample exposed to a flow with known velocity allows the calculation of the erosion rate from the ratio between the sample height $(\mathrm{mm})$ and the elapsed time (h), according to the following equation:

the soil sample to occur (h).
Where $\dot{Z}$ is the soil erosion rate for a test speed $(\mathrm{mm} / \mathrm{h}), h$ is the height of the

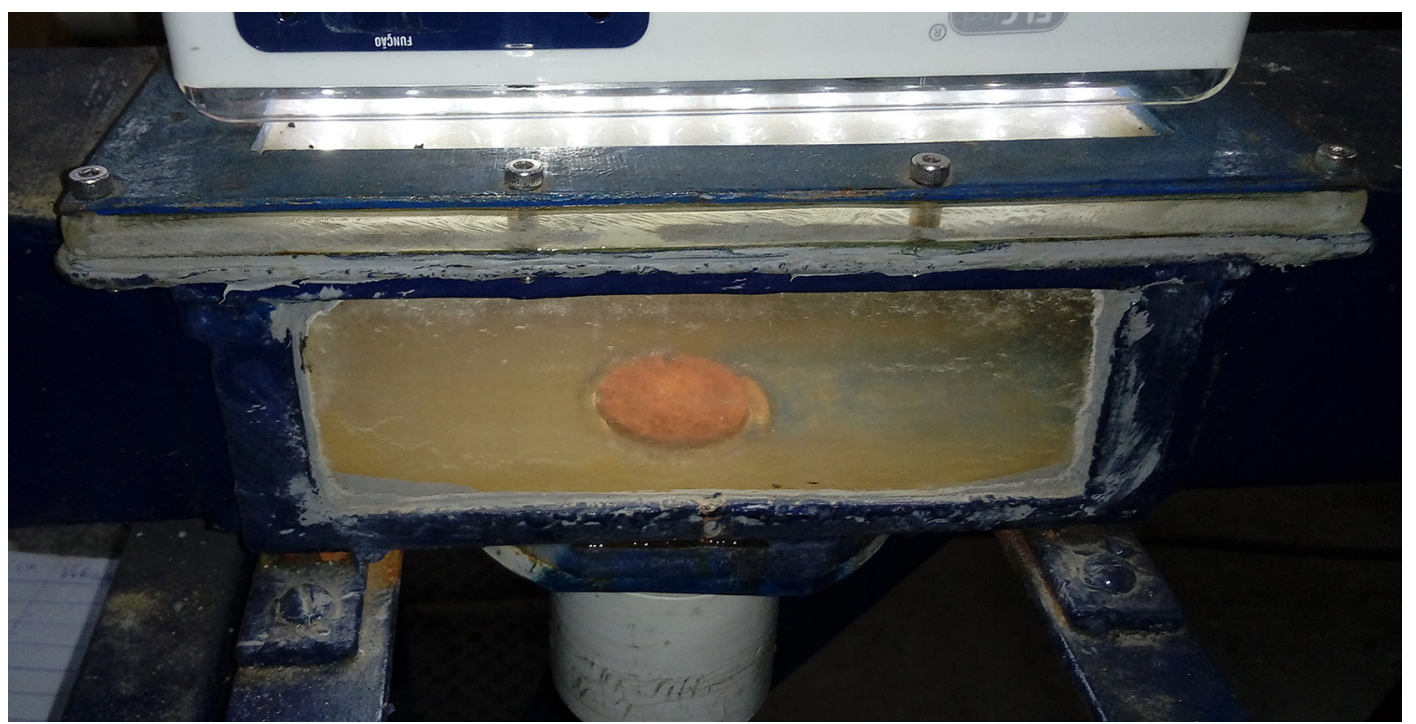

Figure 2 - Sample positioning to start the erodibility test.

\section{Results}

The results demonstrated a considerable reduction in the soil erodibility factor when stabilized with lime for both the Normal Proctor (NP) and reduced compaction tests. The indicated erodibility for each sample used in the test is shown in Table 1 and Figure 3. 
Table 1 - Erodibility for natural soil and soil with lime addition under two compaction conditions and three test velocities.

\begin{tabular}{|c|c|c|c|c|c|c|c|}
\hline \multirow{3}{*}{ Compaction } & \multirow{3}{*}{$\begin{array}{l}\text { Flow velocity } \\
(\mathrm{m} / \mathrm{s})\end{array}$} & \multicolumn{6}{|c|}{ Erodibility $(\mathrm{mm} / \mathrm{h})$} \\
\hline & & \multicolumn{3}{|c|}{ Lime-treated soil ( $3 \%$ lime addition by mass) } & \multicolumn{3}{|c|}{ Natural soil } \\
\hline & & Sample 1 & Sample 2 & Sample 3 & Sample 1 & Sample 2 & Sample 3 \\
\hline \multirow{3}{*}{$\begin{array}{l}\text { Reduced } \\
(30 \% \text { NP) }\end{array}$} & 1.00 & 612 & - & - & 2340 & - & - \\
\hline & 1.75 & 708 & 678 & 897 & 1920 & 4428 & - \\
\hline & 2.50 & 840 & 1644 & 792 & 8100 & 9432 & - \\
\hline \multirow{3}{*}{$\begin{array}{l}\text { Normal Proctor } \\
\qquad(\mathrm{NP})\end{array}$} & 1.00 & - & - & - & 1008 & 2862 & - \\
\hline & 1.75 & 504 & 372 & - & 3384 & 2113 & - \\
\hline & 2.50 & 228 & 480 & - & 3471 & 1800 & 8400 \\
\hline
\end{tabular}

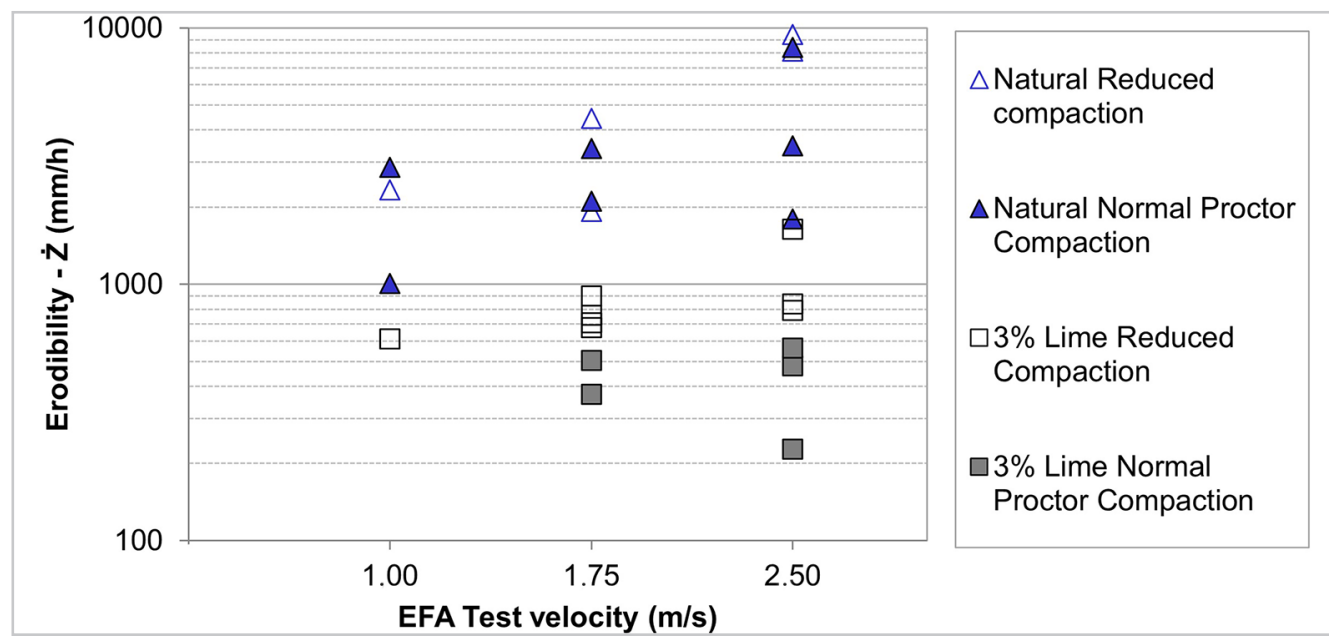

Figure 3 - Erodibility of natural and lime-treated soil samples, produced with reduced and Normal Proctor Compaction energies.

\section{Discussion}

The results corroborate three main issues around soil erodibility. First, soils exposed to a higher flow velocity (or shear stress) showed greater susceptibility to erosion, especially soils with lower compaction degrees and soils without any chemical treatment.

The lime addition allowed the significant reduction of erodibility for the three velocity conditions and the two compaction conditions. The erodibility of lime-treated soils represented between $26 \%$ and $12 \%$ of the soil's values untreated and under reduced compaction. The values range from $16 \%$ to $7 \%$ for the condition of controlled compaction.

The lime-treated soil close to the Proctor Normal compaction showed values below $500 \mathrm{~mm} / \mathrm{h}$ for speeds of $1.75 \mathrm{~m} / \mathrm{s}$ and $2.50 \mathrm{~m} / \mathrm{s}$. Compared to the same compaction condition, untreated soils showed erodibility values between

\section{Conclusions}

The lime addition to soil benefits functions including workability, stability, low permeability, resistance to runoff,
$1000 \mathrm{~mm} / \mathrm{h}$ and $4500 \mathrm{~mm} / \mathrm{h}$.

In most of the tests performed with lime, a stabilized hydrodynamic shape formed. For further studies, the authors recommend testing with flow velocities higher than $2.55 \mathrm{~m} / \mathrm{s}$. In reduced compaction, the natural soil eroded with the ascent rate, suggesting smaller flow velocity testing.

The lime-treated soil showed greater cohesion between grains. This effect is advantageous because it allows the loose particles to settle more quickly, combating the increase in turbidity. The authors recommend the investigation of this hypothesis in further studies.

The effect of soil compaction on erodibility is of great relevance. According to the tests, the erodibility reduced considerably for better compaction in both cases, which corroborates the results obtained by Saliba (2009), who evaluated the two compaction conditions for untreated soils and observed a reduction from $13 \%$ to $48 \%$ on soil erodibility with higher compaction.

The lime results indicated that the lime addition reduced soil erodibility even for poor compaction conditions. This result is of great relevance for places where proper compaction is impossible, either due to difficult access, lack of machinery, or inadequate climatic conditions.

Besides, the results for the Proctor Normal compaction with lime addition indicate increased resistance after just one week of curing, which is already a good indication of application on the mentioned surfaces to combat erosion. Erodibility tends to decrease the longer the curing time to form the pozzolanic reactions of lime. It may still increase the soil resistance to erosion after two years of application (Herrier et al., 2014). and internal erosion, which are relevant indicators to contain erosion. The results obtained in this study indicated that the erodibility of lime-treated soils, with 3\% lime addition by mass, represents between $26 \%$ and $12 \%$ of the values obtained from 
untreated soils, both under reduced compaction. The values ranged from $16 \%$ to $7 \%$, if controlled compaction is adopted.

In the case of Solar Parks, lime can be applied in the soil of accesses, fences, natural thalwegs with high slopes, hydraulic structures of the drainage system, such as slopes of detention basins, windrows, downstream energy dissipators, gabion walls, and hydraulic channels. It is noteworthy that the application should be evaluated for other environments with issues related to erosion, such as mining facilities.

It is worth mentioning that some

\section{Acknowledgements}

The authors acknowledge TEC3 Geotecnia e Recursos Hídricos Ltda. for funding points eventually interfered with the analysis of results. Therefore, further experiments should consider: carry out many tests to ensure a better confidence interval for the observed results; install a larger reservoir that allows the performance of a greater number of tests without increasing turbidity and water temperature; automation of the hammer rise when 1 mm of sample erosion occurs, as results may change according to the difficulty of raising the hammer by the one who performs the test.

Results suggested testing flow ve- locities above $2.5 \mathrm{~m} / \mathrm{s}$ to expand the possibilities of applying this technique to reduce erodibility in hydraulic works for lime-treated soils and determine the optimum dosing according to the soil type. These tests could also highlight the lime treatment's advantages and evaluate the effects of lime dosing in the transport of eroded sediments and the flow's turbidity.

Finally, this complementary study should provide a basis to evaluate the technique's economic feasibility, specific points of application, and corresponding execution methods.
EFA development at $\mathrm{CPH}$ and Lhoist do Brasil for providing lime to the erosion tests.

\section{References}

ASSOCIAÇÃO BRASILEIRA DE NORMAS TÉCNICAS. ABNT NBR 6453: Cal virgem para construção civil Requisitos. Rio de Janeiro: ABNT, 2003.

ASSOCIAÇÃO BRASILEIRA DE NORMAS TÉCNICAS. ABNT NBR 6502: Rochas e solos. Rio de Janeiro: ABNT, 1995.

AZEVEDO, A. L. C.; OLIVEIRA, A. JR.; PEDROSA, R. A.; RAMALHO, R. W. Estabilização de solos com adição de cal. Monografia (Especialização) - IPUC, Pontifícia Universidade Católica de Minas Gerais, Belo Horizonte, 1998.

AZEVEDO, A. L. C. Estabilização de solo com adição de cal. Um estudo a respeito da reversibilidade das reações que acontecem no solo após a adição de cal. 2010. 114 f. Dissertação (Mestrado Profissional em Engenharia Geotécnica) - Escola de Minas, Universidade Federal de Ouro Preto, Ouro Preto, 2010.

BALDOVINO, J. A.; MOREIRA, E. B.; TEIXEIRA, W.; IZZO, R. L. S.; ROSE, J. L. Effects of lime addition on geotechnical properties of sedimentary soil in Curitiba, Brazil. Journal of Rock Mechanics and Geotechnical Engineering, v. 10, n.1, 1, p. 188-194, 2018.

BELL, F. G. Lime stabilization of clay minerals and soils. Engineering Geology Journal, v. 42, n. 4, p. 223-237, 1996.

BERTONI, J.; LOMBARDI NETO, F. Conservação do solo. 4. ed. São Paulo: Ed. Ícone, 1999. 335p. (Coleção Brasil Agrícola).

BRIAUD, J.; TING, F.; CHEN, H.; CAO, Y.; HAN, S.; KWAK, K. Erosion function apparatus for scour rate predictions. Journal of Geotechnical and Geoenvironmental Engineering, v. 127, n. 2. 2001.

CHOW, V. T. Open-channel flow. New York: McGraw-Hill, 1959. 680p.

DALLA ROSA, A. Estudos dos parâmetros-chave no controle da resistência de misturas solo-cinza-cal. 2009. Dissertação (Mestrado em Engenharia Civil) - Escola de Engenharia, Universidade Federal do Rio Grande do Sul, Porto Alegre, 2009.

ELANDALOUSSI, R.; BENNABI, A.; DUPLA, J. C.; CANOU, J.; BENAMAR, A.; GOTTELAND, P. Effectiveness of lime treatment of coarse soils against internal erosion. Geotechinical and Geological Engeneering, v. 37, p. 139-154, 2019.

HERRIER, G.; PUIATTI, D.; CHEVALIER, C.; FROUMENTIN, M.; BONELLI, S. Lime treatment: new perspectives for the use of silty and clayey soils in earthen hydraulic structures. In: ICOLD EUROPEAN CLUB SYMPOSIUM, 9., 2013, Venice, Italy. Proceedings [...]. Venice, Italy: ICOLD, 2013.

HERRIER, G.; CHARLES, I.; CHEVALIER, C.; DURAND, E., PUIATTI, D.; FLEUR EAU, J.-M.; TAIBI, S.; BONELLI, S.; FRY, J.-J. A real scale experimental dike in lime-treated soil: evaluation of the methodology, mechanical and hydraulic performance. In: INTERNATIONAL CONFERENCE ON SCOUR AND EROSION, 7., 2014, Perth, Australia. Proceedings [...]. Perth, Australia: IRC, 2014. p. 521-552.

HERRIER, G.; CAMPOS, N.; NERINCX, N.; BONELLI, S., PUIATTI, D. Lime treatment of soils: A solution for Erosion-resistant Hydraulic Earthen Structures. In: INTERNATIONAL DAM WORLD CONFERENCE, 3., 2018, Foz do Iguaçu, Brazil. Proceedings [...]. Foz do Iguaçu, Brazil: ICOLD, 2018.

LOVATO, R. S. Estudo do comportamento mecânico de um solo laterítico estabilizado com cal, aplicado a pavimentação. 2004. Dissertação (IMestrado em Engenharia Civil) - Escola de Engenharia, Universidade Federal do Rio Grande do Sul, Porto Alegre, 2004.

MANTOVANELLI, G. B. Uma abordagem experimental para a obtenção da taxa de erosão de solos através de um aparato do tipo pistão. 2016. Dissertação (Mestrado em Engenharia Civil) - Centro Tecnológico, Universidade Federal do Espírito Santo, Vitória, 2016. 
MEHENNI, A.; CUISINIER, O.; MASROURI, F. Impact of lime, cement, and clay treatments on the internal erosion of compacted soils. Journal of Materials in Civil Engineering, v. 28, n. 9, 2016.

NEVES, E. N. S. A. C. Estudo laboratorial de solos tratados com cal: modelos de comportamento. 2009. $176 \mathrm{f}$. Dissertação (Mestrado em Mecânica dos Solos e Engenharia Geotécnica) - Faculdade de Engenharia, Universidade do Porto, Porto, 2009.

SALES, M. M.; CARVALHO, J. C.; MASCARENHA, M. M. A. (org.). Erosão em borda de reservatório. Goiânia: Gráfica UFG, 2017. 584p.

SALIBA, A. P. M. Uma nova abordagem para análise de ruptura por galgamento de barragens homogêneas de solo compactado. 2009. Tese (Doutorado em Saneamento, Meio Ambiente e Recursos Hídricos) - Escola de Engenharia, Universidade Federal de Minas Gerais, Belo Horizonte, 2009.

TAVARES, M. H. F.; CARDOSO, D. L.; GENTELINI, D. P.; GABRIEL FILHO, A.; KONOPATSKI, E. A. Uso de forno de microondas na determinação da umidade em diferentes tipos de solo. Ciências Agrárias, v. 29, n. 3, p. 529-538, 2008.

VILAR, O. M. Formulação de um modelo matemático para a erosão dos solos pela chuva. 1987. 196 f. Tese (Doutorado em Geotecnia) - Escola de Engenharia de São Carlos, Universidade de São Paulo, São Carlos, 1987.

WILKINSON, A.; HAQUE, A.; KODIKARA, J.; ADAMSON, J.; CHRISTIE, D. Improvement of problematic soils by lime slurry pressure injection: case study. Journal of Geotechnical and Geoenvironmental Engineering, v. 136, n. 10, p. 1459-1468, 2010.

ZHANG, L.; WANG, J.; BAI, Z.; CHUNJUAN, L.V. Effects of vegetation on runoff and soil erosion on reclaimed land in an opencast coal-mine dump in a loess area. Catena, v. 128, p. 44-53, 2015.

Received: 17 December 2020 - Accepted: 1 April 2021. 